\title{
Analogía escultórica entre la obra leonesa y sevillana de Luis Salvador Carmona
}

Ezequiel A. Díaz Fernández

\begin{abstract}
RESUMEN. Queremos contribuir con nuevas propuestas de atribución a la dilatada nómina escultórica de uno de los más destacado artistas españoles del "olvidado" siglo XVIII. Estudiaremos el conjunto de piezas carmonescas conservado en la región más meridional de la península, interrelacionando cada una de las obras andaluzas con sus homónimas leonesas tras un riguroso cotejo. La presencia de este grupo de esculturas en un espacio geográfico tan exclusivamente localizado y apartado de la capital, se explica por la vinculación que tuvo con el ambiente cortesano y madrileño el VII Marques de Estepa, patrono y benefactor de las iglesias de esta insigne villa sevillana.

Palabras clave: Barroco, rococó, neoclasicismo, académico, estilo carmonesco, escultura del siglo XVIII, cortesano.

ABSTRACT. We want to contribute with new proposals of one of the most important Spanish sculptor from XVIII century. We are going to do a brief study about Luis Salvador Carmona work: “There are some sculptures of Luis Salvador Carmona located in the southern of Spain (Estepa, Seville). We will contrast between Andalusian sculptures and other Carmona sculptures. The presence of this sculpture group in this area it is due to VII Marquis of Estepa. The Marquis of Estepa knows the ambient of the court painters, sculptors and so on. For this reason there are sculptures in this area of Andalusia by Luis Salvador Carmona".

Key words: Baroque, rococo, neoclassicism, academic, carmona's style, sculpture XVIII century, of the court.
\end{abstract}

\section{INTRODUCCIÓN}

La proliferación de investigaciones sobre la obra del vallisoletano junto con el pormenorizado estudio artístico, técnico, estilístico, compositivo e iconográfico de su valiosa producción, están dando a conocer la destacada capacidad de uno de los escultores más relevantes del ámbito artístico de la España dieciochesca. Aferrado estilísticamente al barroquismo desarrolla su creatividad artística dentro del periodo rococó continuando con la lógica evolución hacia la transición neoclásica. De manera acerta- da ha sido reconocido como el mejor imaginero castellano de su tiempo ${ }^{1}$ y maestro del rococó ${ }^{2}$, la categoría artística de que gozó el castellano-leones en su tiempo queda patente en citas textuales de la época.

$\mathrm{Su}$ excepcional valoración historiográfica se justifica en la acertada manera de entrelazar la imaginería tradicional de vertiente castellano-andaluza de eminente

\footnotetext{
${ }^{1}$ F. J. SÁNCHEZ CANTÓN, Escultura y pintura del siglo XVIII, Ars Hispaniae, Madrid, 1958, pp. 263-264.

2 J. J. MARTín GONZÁLEZ, Escultura barroca castellana, Fundación Lázaro Galdiano, Madrid, 1959, pp. 428432.
} 
sentido devocional y popular, con la suntuosa escultórica aristocrática de influencia francoitaliana propia del ámbito cortesano. $\mathrm{Su}$ arraigado corpus barroco se cimenta, entre otros aspectos, en la influencia de su maestro Juan A. Villabrille y $\operatorname{Ron}^{3}$, y en el conocimiento de las elegantes e influyentes obras de los maestros Gregorio Fernández y Pedro de Mena conservadas en Madrid y Nava del Rey. Del estilo seiscentista tomó el gusto por las composiciones abiertas, por una estructuración dinámica de sentido diagonal, junto con el movimiento berniniano de los ropajes llevados por el viento. Con la evolución estética hacia el rococó la vinculación e influencia de Doménico Olivieri reportara a su obra la aristocrática distinción de una elegante vitalidad que reconocerá al académico como uno de los grandes e insignes artífices, héroe en su facultad de inmortal memoria, la que dejó y quedará perpetuada en las mudas, si bien vivas, hechuras de su $\mathrm{mano}^{4}$. El conjunto escultórico estepeño, en una zona tan meridional, contribuirá a incrementar la expansión geográfica de su obra así como la nómina productiva de tan prolijo y preclaro artista.

Desde el punto de vista historiográfico la contrastada valía del académico se fundamenta en la sabia interrelación entre una escultótica tradicional y devocional, combinada con otra eminentemente europeizante y aristocrática. De forma admirable sabrá interpretar los preceptos escultóricos de la imaginería de estirpe catellanoandaluza, aunque desposeídos de aquel exacerbado dramatismo seiscentista, im-

\footnotetext{
${ }^{3}$ S. SALORT PONS, "Juan Alonso Villabrille y Ron, maestro de Luis Salvador Carmona", Archivo Español de Arte (AEA), 280, Madrid, 1997, pp. 454-457.

${ }^{4}$ Compendio de la vida y obras de D. Luis de Salvador y Carmona, Theniente-Director de Esculptura que fue de la Real Academia de las Tres Nobles Artes. Año de 1775. Archivo de la Real Academia de San Fernando 82-2/4. J. J. MARTín GONZÁLEZ, Luis Salvador Carmona, Escultor y Académico, 1990, Madrid, pág. 36.
}

buidos ahora dentro de un nuevo lenguaje clasicista y cortesano, alejado de aquel afectado patetismo cruento para vincularse a los nuevos valores definidos por la elegancia, espiritualidad, distinción y equilibrio de la transición entre el rococó y el neoclasicismo. Estos elementos vertebraran la capacidad creativa y compositiva de tan preciado escultor. Es indiscutible la calidad escultórica de Luis Salvador Carmona ${ }^{5}$ (1708-1767), dentro del panorama artístico del siglo XVIII en España.

La finalidad de este artículo es dar a conocer un conjunto de obras conservadas en la localidad sevillana de Estepa del segundo tercio del siglo XVIII, que ha estado "escondido" en las sombras de la indiferencia hasta hace pocos años. Para entender mejor la producción artística de este escultor hay que adentrarse en aquellos aspectos fundamentales de la época en la que estas obras vieron la luz. Es este un período dominado por el pensamiento "ilustrado", que fue introducido en la corte española junto con la monarquía borbónica. Este clima favoreció la creación de la Real Academia de Bellas Artes de San Fernando en 1741, de la que formó parte Luis Salvador Carmona como "Teniente-Director de Escultura". Esta institución se convirtió en la puerta de entrada de las manifestaciones plásticas y la estética dominante en la corte de Francia y que vino a sustituir a aquellas influencias italianas que predominaron durante la mayor parte del siglo XVII. No

\footnotetext{
5 J. J. MARTín GONZÁLEZ, Escultura barroca en España (1600-1770), Cátedra, Madrid, 1983, pp. 380-390. E. A. LORD, "Luis Salvador Carmona en el Real Sitio de San Ildefonso (La Granja), Archivo Español de Arte (AEA), Madrid, 1951, pp. 11-29. J. J. MARTín GONZÁLEZ, "La escultura en Valladolid durante el siglo XVIII", T. V, Ateneo, Valladolid, 1984, pág. 333. J. L. MORALES Y MARÍN, Arte español en el siglo XVIII (Escultura), T. XXVII, Summa Artis, Madrid, 1996, pp. 388393. J. MORENO VILLA, "Memorial del escultor D. Luis Salvador Carmona", Archivo Español de Arte y Arqueología, T. VIII, Madrid, 1932, pp. 98-99.
} 
hay que olvidar que la Academia de Bellas Artes siguió el modelo francés de la Academia de París y que al igual que ésta, se convirtió en un instrumento de propaganda política.

Otro aspecto importante y fundamental para entender la llegada de las obras de este escultor a Estepa, es la clientela entre la que se movió y que alcanzó la jerarquía más alta, trabajó para la monarquía en el Palacio Real Nuevo de Madrid, en la Colegiata de La Granja de San Ildefonso y en el Panteón de Carlos V. Esto hizo que se relacionase dentro de los círculos cortesanos donde probablemente conoció al III Marqués de Estepa, que fue el principal promotor y responsable de que hoy día podamos disfrutar en el corazón de Andalucía de un conjunto de obras del vallisoletano.

\section{LA ESCULTURA DIECIOCHESCA ESPAÑOLA: LUIS SALVADOR CARMONA.}

El académico y escultor cortesano, Luis Salvador Carmona, es considerado uno de los más relevantes escultores del panorama artístico de la España dieciochesca por su contrastada dimensión artística y capacidad creativa. Trabaja en el Palacio Real de Madrid realizando las esculturas regias en piedra de Ramiro I, Ordoño II, Dña. Sancha, Felipe IV y Juan V de Portugal. Entre sus adornos realizó trofeos, conchas, cabezas y escudos de armas; además de los relieves de San Isidro Labrador y el de San Dámaso con San Jerónimo. En la Real Academia de Bellas Artes de San Fernando el 2 de mayo de 1746 fue nombrado Teniente-Director de Escultura, para esta institución donó una Vestal (busto de mujer velada que representa la Fe). Para el Real Sitio de San Ildefonso (La Granja) realizó entre otras muchas obras el relieve del Cristo de la Victoria y la Virgen del Rosario en la Colegiata, para Iglesia de Ntra. Señora del Rosario las tallas del Cristo del Perdón y el relieve del Padre Eterno y en la Iglesia de Ntra. Señora de los Dolores (también de La Granja) destaca la efigie de la Dolorosa.

Fuera de este ambiente cortesano su prolija producción artística irradia a toda la península como lo atestiguan sus obras de Madrid, Navarra, Guipúzcoa, Valladolid, Toledo, Cáceres, Salamanca, Segovia, León, Avila o Estepa (Sevilla). De forma admirable sabrá interpretar la estética de los grandes maestros del siglo XVII (como Gregorio Fernández o Pedro de Mena entre otros) dentro del nuevo lenguaje clasicista y cortesano, por lo que será considerado como uno de los grandes maestros del rococó. Sus modelos iconográficos serán los de la escultura tradicional castellana y andaluza del siglo XVII, pero desposeídos de su exacerbado dramatismo y patetismo cruento, destacando y potenciando valores como la elegancia, distinción, equilibrio y mesura.

La categoría artística de que gozó Luis Salvador Carmona en su tiempo queda patente en citas textuales de la época al señalarlo como: celebre escultor español, o de los mejores artífices de la Corte ${ }^{6}$, subrayando el reconocimiento y fama que poseía ya en vida el vallisoletano. Hoy día es ya reconocido como uno de nuestros mejores artistas en su tiempo y se entiende que una importante parte de la escultura española de la segunda mitad del siglo XVIII tiene en Luis Salvador Carmona su indiscutible punto de partida ${ }^{8}$.

\footnotetext{
${ }^{6}$ Ma. C. GARCía GAINZA, El Escultor Luis Salvador Carmona, Universidad de Navarra, Pamplona, 1990, pág. 31. J. A. CEÁN BERMúdeZ, Diccionario Histórico de los más ilustres profesores de las Bellas Artes en España, T. IV, Madrid, 1800, pág. 98.

${ }^{7}$ Cita de Gómez Moreno extraída de Ma ${ }^{2}$ C. GARCíA GAINZA, "Luis Salvador Carmona, imaginero del siglo XVIII", Goya, 124, Madrid, 1975, pp. 206-215.

${ }^{8}$ AA.VV. Catálogo de la exposición Luis Salvador Carmona en Valladolid, Dirección General de Bellas Artes y Archivos, Ministerio de Cultura, Valladolid, 1986, pág. 13.
} 
Consideramos que la aportación más valiosa del escultor castellano a la imaginería policroma barroca dieciochesca será la perfecta combinación entre lo popular y lo aristocrático, entre la tradición y la nueva distinción clasicista, en definitiva entre una realidad impregnada de cotidianidad y un verismo de extremada elegancia cortesana.

\section{LOS MARQUESES DE ESTEPA $Y$ LUIS SALVADOR CARMONA.}

Son diversas las propuestas que explican el foco escultórico perteneciente a Luis Salvador Carmona en Estepa. Consideramos que siendo D. Juan Bautista Centurión y Ayala (1718-1785) VII Marqués de Estepa ministro y benefactor de la Orden Tercera Franciscana estepeña y residente en la capital madrileña, pudo conocer al escultor castellano que también estaba vinculado a la seráfica orden en Madrid. Incluso sabemos que D. Luis Salvador, su padre, era miembro de dicha Orden Tercera y al igual que toda su familia devoto de San Luis ${ }^{9}$ fundador de dicha congregación terciaria. Quizás a raíz de estos vínculos franciscanos pudieron entablar relación y entrar en contacto el Marqués y el académico. Refuerza esta idea según nuestro criterio, el hecho de ser amortajado Salvador Carmona con el hábito franciscano ${ }^{10}$ en la parroquia madrileña de San Sebastián. Otro aspecto interesante será que el VII Marqués de Estepa, D. Juan Bautista Centurión, fue Gentilhombre de Cámara de Su Majestad con ejercicio y Caballero de la Gran Cruz de Carlos III $^{11}$ (1771), por lo tanto como hombre cortesano

\footnotetext{
9 J. J. MARTín GonzÁlez, Luis Salvador Carmona, Escultor...op. cit, pág. 13.

${ }^{10}$ Archivo de la Parroquia de San Sebastián (APSS) de Madrid. Libro de Defunciones, T. 30, pág. 214.

${ }^{11}$ J. De Salazar y J. Gómez De Olea,. “Los Marqueses de Estepa, Estudio Histórico-Genealógico", Actas de las II Jornadas sobre Historia de Estepa, Estepa, 1996, pp. 81-82.
}

pudo conocer el ambiente en el que actuaban estos artistas áulicos, entre los que con toda seguridad se encontraría Luis Salvador Carmona. De la misma forma residía largas temporadas en Madrid y sin lugar a dudas, posiblemente fue uno de los que demandó al escultor castellano algunos de los encargos estepeños. Por lo tanto concluimos, que sin duda alguna la residencia en Madrid de los Marqueses y su estrecha vinculación con el ambiente cortesano, propició el que éstos se erigiesen como intermediarios entre el clero estepeño y el taller del académico.

Además, había que tener en cuenta el prestigio alcanzado por Luis Salvador Carmona ya desde mediados del siglo XVIII, no solo en la Corte, si no en gran parte de España. No en vano encontramos sus obras diseminadas por casi toda la geografía peninsular. De igual manera los Marqueses establecerían un mejor control e inspección del trabajo al residir durante largas temporadas en la capital. Todas estas suposiciones y conjeturas se contrastan documentalmente ${ }^{12}$ por la existencia de una deuda de mil reales que tenía el Marqués de Estepa con dicho escultor por la hechura de una cabeza y manos de un Nazareno para Estepa. Al parecer, se afirma ${ }^{13}$, que las obras estepeñas de San Francisco de Asís, San Juan Bautista y Ntro. Padre Jesús Nazareno fueron ejecutadas en Madrid por el castellano y enviadas por el VII Marques a

\footnotetext{
${ }^{12}$ Ma. C. García Gainza y C. Chocarro BujanDA, "Inventario de Bienes del Escultor Luis Salvador Carmona", Boletín de la Academia de San Fernando, 86, Madrid, 1998, pág. 229. Documentación extraída del Archivo Histórico de Protocolos de Madrid, T. 15.704, pp. 449-454. El manuscrito se fecha el 23 de marzo de 1759 , lo que nos indica que en torno a esta fecha se debió ejecutar la talla del Nazareno estepeño.

13 A. ReCio VeganzonEs, "Dos imágenes barrocas de San Francisco en Estepa, obras de los escultores Luis Salvador Carmona y Miguel Márquez", El franciscanismo en Andalucía, Priego de Córdoba, 1996, pág. 235.
} 
sus respectivos oratorios, ya que éste como patrono de los templos de su marquesado, a la sazón Vicaria Vere Nullius, debía atender a su culto y decencia.

\section{RELACIÓN ENTRE LA ESCULTU- RA LEONESA Y SEVILLANA DE LUIS SALVADOR CARMONA.}

Ha sido reconocido el artista castellano como un escultor rococó que avanza levemente hacia el neoclasicismo en su última época, manteniendo siempre una alta calidad y acierto. Su categoría artística reconocida hace que lo consideremos como el mejor escultor de su época ${ }^{14}$. Sin lugar a dudas buena muestra de este colosal arte carmonesco serán las imágenes de la localidad sevillana de Estepa.

La imagen de San Francisco de Asís, de la estepeña Iglesia de Nuestra Señora de Gracia (Convento Franciscano), fue atribui$\mathrm{da}^{15}$ a las escuelas sevillana y granadina en estudios precedentes, pero será el investigador franciscano Martín Recio ${ }^{16}$ en los

${ }^{14}$ Ma . C. GARCía GAINZA, El escultor Luis Salvador...op. cit. pág. 10.

${ }^{15}$ J. HERNÁNDEZ DíAZ, A. SANCHO CORBACHO, y F. Collantes De Terán, Catálogo Arqueológico y Artístico de la Provincia de Sevilla, T. IV, Sevilla, 1939-55, pág. 80. El Catálogo Arqueológico nos habla de la importantísima imagen de San Francisco de Asís, joya de la escultura barroca española, obra granadina del siglo XVIII, muy relacionada con la producción de Mena, el crucificado que lleva en la mano es interesante y de análoga filiación artística. El Catálogo del Palacio de Arte Antiguo de la Exposición Iberoamericana, $\mathrm{n}^{\circ}$. 1230. Lo atribuye a Martínez Montañés o a Pedro de Mena. A. AgUILAR Y CANO, Memorial Ostipense, Granada, 1886, pág. 340. Lo considera de origen italiano, aunque también plantea la posible autoría de Martínez Montañés. A. MORALES, Ma․ J. SANZ, J. M. SERRERA, y E. VAldivieso, Guía Artística de Sevilla y su provincia, Sevilla, 1981, pág. 650. Nos dice que presenta afinidades con la escuela granadina de finales del siglo XVII, aunque también con los círculos madrileños de principios del siglo XVIII. Este último estudio deja entrever la posible filiación con los talleres madrileños donde actuaba Salvador Carmona.

${ }^{16}$ M. RECIO, “¿Un Salvador Carmona en Estepa?”, Archivo Español de Arte (AEA), T. 47, Madrid, 1974, pág.
}

años setenta el que relacionará esta obra con Luis Salvador Carmona. Fundamenta esta teoría tras la aparición de una serie de pagos en el libro de acuerdos de la Venerable Orden Tercera de penitencia de N. S. P. San Francisco ${ }^{17}$ entre 1743 y 1746, para la adquisición de una talla del seráfico padre y su correspondiente retablo, por mediación del VII Marqués de Estepa D. Juan Bautista Centurión y Ayala como hermano y ministro que era de la corporación franciscana. Valiéndose de la mencionada cita documental, el investigador franciscano vinculará esta talla al círculo de Salvador Carmona tras el riguroso cotejo y estudio llevado a cabo con su homónima del Museo de León. A raíz de esta investigación la profesora García Gainza relacionará la obra estepeña con otra de la localidad navarra de Olite, realzando más si cabe la extremada analogía y similitud entre ambas esculturas.

La magnífica talla del "Poverello" que conserva el cenobio franciscano es considerada como un bellísimo alarde de extremado misticismo, verdadera representación del ascetismo eremítico y genuina expresión de la más pura imaginería tradicional y europeizante del siglo XVIII. Se trata de una interpretación dieciochesca de la iconografía seráfica de Alonso y Pedro de Mena. Avanza el pie izquierdo decidida-

330. A raíz de este estudio también se hace referencia a esta imagen en Mª . C. GARCÍA GAINZA, El Escultor Luis Salvador Carmona...ob. cit. pág. 92. J. J. MARTÍN GONZÁLEZ, Luis Salvador Carmona, Escultor...op. cit, pp. 281285. E. GÓMEZ PIÑOL, “La imagen de Nuestro Padre Jesús Nazareno de Estepa, una propuesta de atribución a Luis Salvador Carmona", Actas de las II Jornadas sobre Historia de Estepa, Estepa, 1996, pp. 535-557.

${ }^{17}$ Actas de los Libros de Acuerdos de la Venerable Orden Tercera de penitencia de Nuestro Seráfico Padre San Francisco de Asís de la Villa de Estepa (1686-1766), conserva las actas de elecciones de cargos y oficios, las visitas canónicas de los comisarios de la orden tercera y el estado de cuentas. (A)rchivo del (C)onvento de (S)an (F)rancisco de Estepa. En 1743 se habían abonado (al vallisoletano) 733 reales de vellón, pero aún en 1746 se continua pagando la imagen. 
mente retrasando el derecho lo que acentúa su actitud itinerante sobre la peña abrupta en la que se ubica. Su cadera se desliza hacia la izquierda en la apertura del paso firme, lo que provoca el sinuoso balanceo hacia este lado de los bajos del hábito. De esta forma los pliegues de la estameña acentuaran su convexidad en la pierna que avanza, desapareciendo al tiempo en la pierna que se retrasa. Porta en su mano izquierda un interesante crucificado que acerca a su rostro, la envolvente contemplación de Cristo estructura el conjunto de la obra, mientras el brazo derecho se extiende abriendo el conjunto de la composición. Es evidente que el juego de apertura de líneas y de recogimiento sobre sí mismo de los brazos incide de manera muy favorable en el dinamismo, teatralidad y creatividad del esquema que vertebra la obra. La cabeza se inclina hacia la izquierda buscando la presencia del Redentor, pero su mirada no se concentra en la divina admiración de Cristo crucificado, si no que se pierde extasiada, entregada y obnubilada, adentrándose con místico fervor en la inconmensurable profundidad del alma de Dios. Su cabeza es enteca, con facciones enjutas y visibles arrugas.

El estudio anatómico de la cabeza y manos es espléndido, el modelado ondulante de su faz incide en su expresión cenceña y magra, sutiles venas en las sienes, leves arrugas en la frente, mejillas macilentas y hundidas, y salientes pómulos conforman su magnífico semblante. El rostro se enmarca por el cabello de la frente que se acumula en el centro y por una barba ligeramente bífida. Los estigmas realzan la veracidad y vivacidad de tan portentosa efigie. La serenidad y sosiego que fluyen de esta pieza radica en la ternura y pasión incontenible con la que el "Poverello" admira, contempla y casi advierte las divinas palabras de su maestro. La imagen de Cristo crucificado que porta en la siniestra posee una cuidada anatomía y una delicada ele- gancia, desposeída del efectismo traumático y de exacerbados dramatismos propios de la más pura imaginería cristífera de nuestro genuino barroco. Destaca su brillante policromía y su carnación a pulimento con finos y expresivos regueros de sangre que de forma tenue manan de sus heridas. La distinción, el porte, la serenidad y la dulzura serán los elementos estilísticos que configuraran la composición de este tipo de imágenes carmonescas.

La talla de San Francisco de Asís del Museo provincial de León es obra de vestir, ejecutada a mediados del siglo XVIII, en la que destaca su espléndida cabeza y sus expresivas manos. El modelado de su testa denota una blandura de formas que se acentúa en sus demacrados pómulos y mejillas. La boca entreabierta, las delicadas venas de las sienes, las expresivas cejas y su turbadora mirada, evocan un inusitado misticismo subrayado por la ascética expresión de su portentosa faz. La imagen estepeña del seráfico padre mantiene una clara y estrecha relación con la leonesa, así lo atestiguan los diferentes pormenores como las mejillas rehundidas, las venas en las sienes, la boca entreabierta, etc. La talla castellana parece mostrar mayor afinamiento en el acabado de la barba, así como al fruncir de forma ostensible el ceño manifiesta un sentimiento de carente sosiego y angustia contenida. Muestra un rostro más alargado al pronunciarse la perilla de la barba que aún no se hace definitivamente bífida.

La devota imagen de Nuestro Padre Jesús Nazareno, perteneciente a la Iglesia parroquial de San Sebastián de Estepa, estaba también reconocida como obra grana$\operatorname{dina}^{18}$, pero fue vinculada ${ }^{19}$ al escultor $y$

\footnotetext{
-

18 J. HERNÁNDEZ DÍAZ, A. SANCHO CORBACHO, y F. Collantes De Terán, Catálogo Arqueológico...op. cit, Pag. 54. Nos dice que el Nazareno es una escultura granadina del primer cuarto del siglo XVIII, inspirada en las
} 
académico vallisoletano tras el estudio comparativo llevado a cabo con sus homónimas de La Bañeza (León) y el Real de San Vicente (Toledo). Y ratificada como obra carmonesca tras el hallazgo por parte de la profesora García Gainza de un interesantísimo manuscrito en el Archivo Histórico de Protocolos de Madrid ${ }^{20}$. La mencionada cita documental corresponde en concreto al inventario de bienes del escultor Luis Salvador Carmona efectuado tras la muerte de su primera esposa. Ante su intención de contraer nuevo matrimonio, realiza la partición de los bienes que han quedado por muerte de doña Custodia Fernández, en el que se expresa que se adeudaban al escultor mil reales, por parte del Marqués de Estepa por la echura de una cabeza y manos para una efigie de Jesús Nazareno que tiene mandados hacer $y$ al presente tiene. El documento se fecha en 1759 lo que indica que por esta fecha se debió ejecutar la cabeza y manos del Nazareno.

La existencia de una talla anterior a la actual es señalada por un documento de $1694^{21}$. Complementamos y ratificamos esta afirmación tras la aparición de un inventario de la capilla de Jesús Nuestro Señor de

obras de José Risueño, (...) las piernas y pies se hicieron en 1883 por Gumersindo Jiménez Astorga. A. MORALES, Ma. J. SANZ, J. M. Serrera, y E. VAldivieso, Guía Artística...op. cit, pag. 643. Lo encuadran dentro de la escuela granadina de la primera mitad del siglo XVIII. A. AGUILAR Y CANO, Memorial Ostipense...op. cit, pág. 324. Insinúa su posible filiación al círculo Montañesino. E. A. DíAz FERNÁNDEZ, "La Cofradía de Nuestro Padre Jesús Nazareno durante los siglos XVII y XVIII", Actas de las V Jornadas sobre Historia de Estepa, Estepa, 2002, pp. 112-116. E. A. DíAZ FERNÁNDEZ, “Nuevas obras de Luis Salvador Carmona en Estepa", Estepa, 2003, pp. 7-11, (inédito).

${ }^{19}$ E. GÓMEZ PIÑOL, “La imagen de Nuestro Padre Jesús Nazareno...op. cit, pág. 535.

${ }^{20}$ Ma. C. García Gainza, y C. CHOCARro BujanDA, "Inventario de Bienes del Escultor Luis Salvador Carmona...op. cit, pág. 229.

21 (A)rchivo (G)eneral del (A)rzobispado de (S)evilla, Sección V, Vicaria de Estepa, Legajo 11, 1694, Inventario de la Iglesia parroquial de San Sebastián.
$1707^{22}$ en el que se especifica de manera pormenorizada los enseres e imágenes que poseía dicha Hermandad a principios del siglo XVIII. Este interesante inventario nos habla de la presencia ya conocida de la ymagen de Jesús anterior a la actual y las de Nuestra Señora y Señor San Joan, todas con sus respectivos atavíos, ropajes y enseres.

La primitiva talla de Jesús Nazareno como la de San Juan Evangelista poseían el elemento arcaizante del cabello natural. Esta característica, hoy día en la efigie carmonesca, debe ser entendida dentro de un anquilosamiento estético, formal e incluso devocional que pervive y se mantiene aún en el comedio del siglo XVIII. Sin duda, la Hermandad fue reacia en todo momento a desprenderse de este tradicional arcaísmo, por lo que quizás al sustituir esta efigie hacia mediados del siglo XVIII los hermanos solicitarán a Salvador Carmona que la nueva talla mantuviese y preservase este rasgo perentorio de la primitiva efigie. Pertenecen al escultor castellano la cabeza y las manos ya que el resto del cuerpo es posterior. El rostro se enmarca por una melena de pelo natural tocado con corona de espinas dorada. La barba ejecutada con minuciosidad se hace fina y escueta en la mandíbula con el fin de destacar la palidez y el juego de planos de sus mejillas enjutas.

Una vez más, el dominio de la capacidad plástica y estética del académico queda de manifiesto en la búsqueda de la emotividad, por medio de una expresión apesadumbrada y a la vez dulce que confiere al espectador un hondo sentimiento de aflicción contenida, sumisión redentora y sufrimiento interno. La reiterada expresión lastimera, dolorida y elegante vuelve a ser el recurso para mostrar la depurada faz del Nazareno estepeño. La angustia reprimida,

22 A.G.A.S., Sección III, Serie JusticiaHermandades, Legajo 136, 1707, Inventario de la Capilla de Nuestro Padre Jesús Nazareno. 
el desfallecimiento humano y la frágil levedad del hombre terrenal se manifiestan en este rostro con una veracidad meridiana, pero al mismo tiempo apreciamos la sumisión a la voluntad del Padre, la infinita capacidad de sufrimiento, la imperturbable serenidad en su sacrificio y el colosal porte de su divinidad. Este dulce semblante de manera patente aúna la debilidad humana del hombre ante el escarnio y la humillación de sus congéneres, y el poder sobrenatural y divino del hijo de Dios. De nuevo la virtuosa gubia del vallisoletano de manera sorprendente da vida a Cristo, esta vez cargado con la cruz en el cruento camino hacia la muerte. Consideramos que Salvador Carmona consigue de manera magistral enlazar en esta obra la divinidad y la humanidad de Cristo. Su frente limpia apenas se perturba al fruncir el ceño levemente y sus ojos abatidos miran al suelo perdiendo la mirada. El cenceño modelado de mejillas y pómulos se estructuran por medio de planos hundidos y resaltados dando un modelado sinuoso que acentúa su ascetismo y carácter casi famélico. Estos rasgos son más tenues que los del Precursor estepeño del mismo templo, aunque ambos rostros mantienen una misma línea y estrecha similitud estilística.

La mirada abatida y la boca entreabierta inciden en su expresión dolorida y exhausta llegándose a presentir casi, el imperceptible gemido de su extenuada y entrecortada respiración. La delicada barba bífida se compone de superficiales incisiones de sinuosos mechones verticales. Las manos muestran una cuidada anatomía con delgadas falanges de minuciosas venas; Cristo abraza la cruz dulcemente en un lenguaje expresivo de extremada delicadeza. El Nazareno junto con las imágenes de San Francisco de Asís y la de San Juan Bautista conforman la producción más destacada del castellano en tierras andaluzas. La obra de Luis Salvador Carmona, y en especial sus creaciones cristíferas, manifiestan una expresión de sufrimiento extremadamente contenido y atemperado, la angustia y el dolor son mitigados de manera sutil en un exquisito alarde de clasicismo, y la espiritualidad, elegancia, ensimismamiento, distinción y pasión comedida serán los valores que perfilarán su magnífica composición artística.

El Nazareno ${ }^{23}$ de la localidad leonesa de La Bañeza, ejecutado entre 1755 y 1760, presenta unos rasgos estilísticos que lo vinculan estrechamente con la producción del vallisoletano, a razón de la aparente vinculación compositíva con su homónima sevillana. La faz del Nazareno castellano posee a nuestro entender unos rasgos algo más duros y expresivos, como es el caso del acusado ceño fruncido, las espinas que traspasan las cejas, la densa barba apenas bífida y algo recortada y en definitiva la sensación y apariencia de un rostro más lacerado y dolorido. Al enmarcarse el óvalo de la cara por la ondulante melena finamente tallada, el alargamiento facial se contrarrestará por la volumetría y ensanchamiento de la tupida cabellera. Por otro lado la imagen sevillana, aún manifestando los mismos rasgos esenciales de la estética carmonesca, alivia la expresión dolorida por medio de una barba más afinada y menos poblada, sin arquear apenas las cejas y sin marcar en exceso las órbitas oculares, dando una sugerente idea de angustia contenida y de admirable tenacidad y sosiego en el cruento escarnio. Las imágenes de los Nazarenos leones y toledano también ofrecen una evidente proximidad de factura en elementos como la espina que orada la ceja, la espesura y recortamiento de la barba, las facciones enjutas de las mejillas y otra serie de rasgos relacionables con el resto de la

\footnotetext{
${ }^{23}$ J. Ma. LuenGO, “Luis Salvador Carmona: el Jesús Nazareno de La Bañeza (León)", Archivo Español de Arte (AEA), Tomo XXIV, 94, Madrid, 1951, pp. 163-164.
} 
producción nazarena de Salvador Carmona.

\section{CONCLUSIÓN.}

El conjunto de esculturas de Luis Salvador Carmona que se encuentran en la sevillana localidad de Estepa ${ }^{24}$ constatan la categoría artística de uno de los escultores españoles más importantes del siglo XVIII.
Su producción escultórica se inicia con un estilo propio del tradicional barroco castellano y andaluz, prosigue con la adopción de caracteres cortesanos de influencia italofrancesa, se adentra a continuación en la suntuosa estética rococó para finalmente ser participe de la mesurada corriente neoclasicista.

${ }^{24}$ Indice fotográfico: San Francisco de Asís (León), Ma. C. GARCía GAINZA, El Escultor Luis Salvador Carmona...op. cit., pág. 86; Jesús Nazareno, (La Bañeza, León), J. J. MARTín GONZÁLEZ, Luis Salvador Carmona, Escultor y Académico...op. cit., pág. 272.

Nuestra gratitud a Dña. Ana Belén Robles Castro por su constante ánimo y apoyo. 


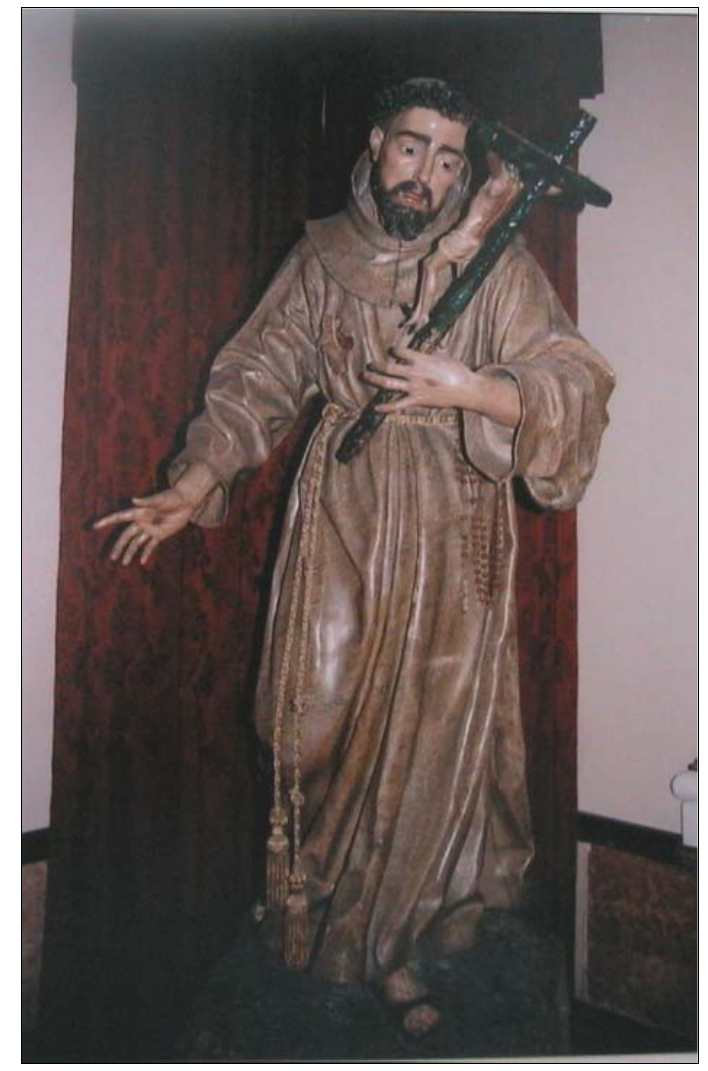

- Lám. 1. Luis Salvador Carmona. San Francisco de Asís. Iglesia conventual de Ntra. Señora de Gracia. Estepa (Sevilla)

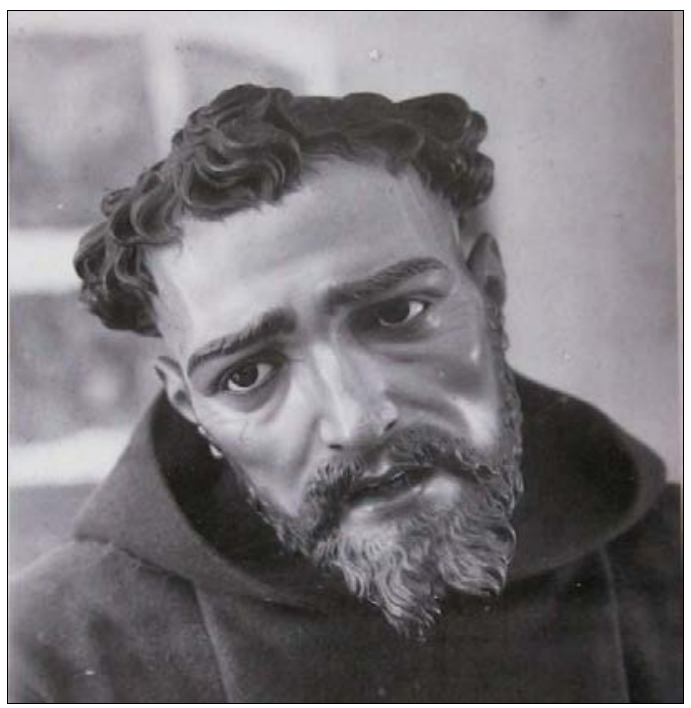

- Lám. 2. Luis Salvador Carmona. San Francisco de Asís. Museo Provincial de León. León.

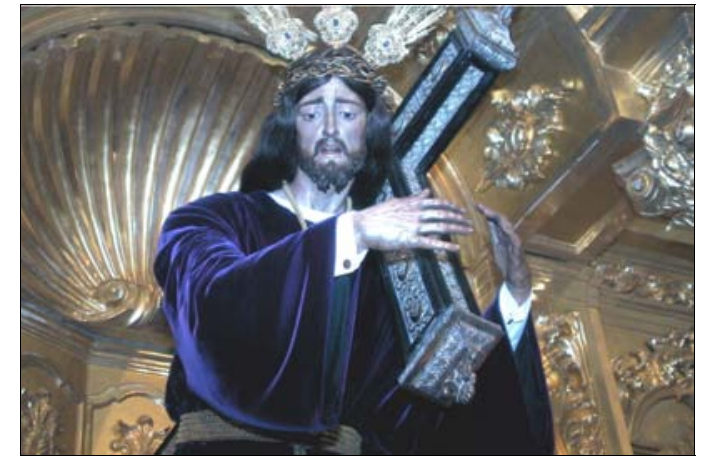

- Lám. 3. Luis Salvador Carmona. Nuestro Padre Jesús Nazareno. Iglesia Parroquial de San Sebastián. Estepa (Sevilla).

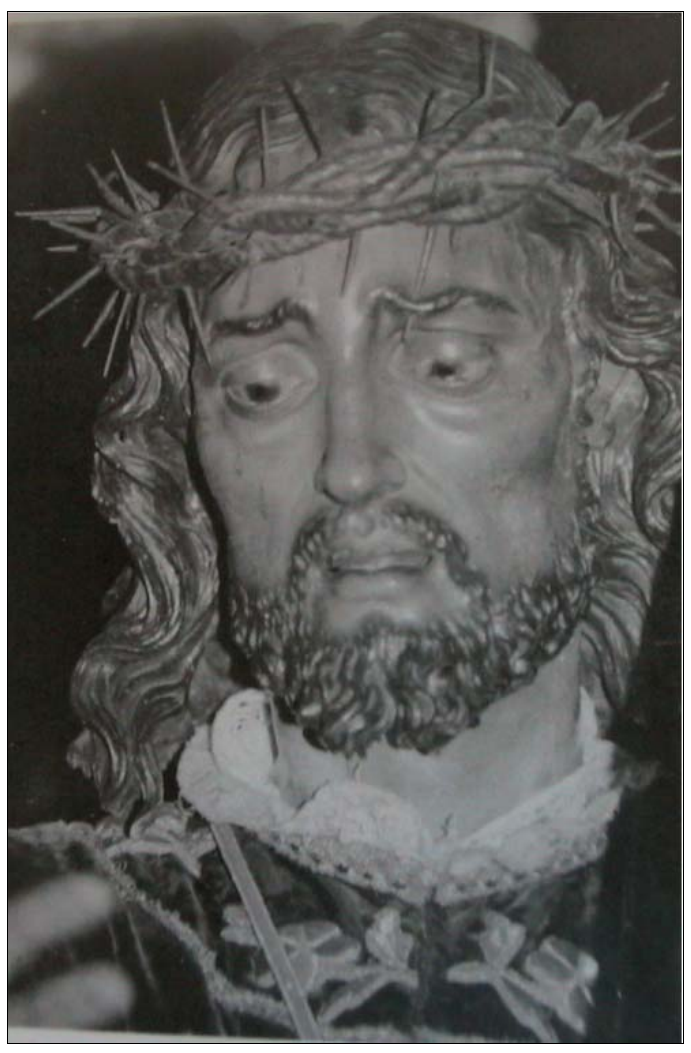

- Lám. 4. Luis Salvador Carmona. Nuestro Padre Jesús Nazareno. Iglesia Parroquial. La Bañeza (León) 